\title{
Principles of lactose crystallization and rheology of milk protein concentrate
}

\author{
Princípios de cristalização da lactose e reologia de concentrado proteico de leite \\ Principios de cristalización de lactosa y reología del concentrado de proteína de leche
}

Recebido: 09/11/2021 | Revisado: 18/11/2021 | Aceito: 25/11/2021 | Publicado: 03/12/2021

Débora Brito Goulart

ORCID: https://orcid.org/0000-0001-6248-2808 University of Wisconsin, Madison, United States of America

E-mail: dbgoulart@wisc.edu

\begin{abstract}
Milk protein concentrate (MPC) is a commercial designation for dairy ingredients with higher protein and lower lactose content than conventional skim milk powder. Lactose in its amorphous form is found in several spray-dried dairy powders. Amorphous lactose is thermodynamically unstable and can mobilize and crystallize over time under adequate temperature and moisture content. Moisture sorption from the air precedes crystallization, enhancing MPC cohesiveness and caking. This increased humidity results in poor rehydration and dispersibility, lower yield during drying, operation problems, difficulties in handling and storage. Moreover, lactose crystallization in MPC can cause Maillard browning reaction and fat oxidation. To avoid this problem, it is necessary to pre-crystallize lactose as alpha-lactose monohydrate, which is non-hygroscopic, before spray drying. Such a procedure is essential in preventing deterioration of MPC resulting from lactose crystallization or chemical reactions. Additionally, the control of this step is important to obtain specified and reproducible powder, in terms of size and crystallization level. There are various reports on the rheology of milk-based products; however, there is a lack of investigation on concentrated systems. Consequently, the objective of the present work is to review basic concepts of lactose crystallization and rheology of milk protein concentrate.

Keywords: Milk protein concentrate; Lactose crystallization; Rheology, Dairy products; Spray dryer; Food engineering; Dairy technology.
\end{abstract}

\section{Resumo}

O concentrado de proteína do leite (MPC) é uma designação comercial para ingredientes lácteos com maior teor de proteína e menor teor de lactose do que o leite em pó desnatado convencional. A lactose em sua forma amorfa é encontrada em diversos produtos lácteos secos por pulverização. A lactose amorfa é termodinamicamente instável e pode se mobilizar e cristalizar com o tempo sob temperatura e umidade adequadas. A absorção de umidade do ar precede a cristalização, aumentando a coesão e a aglutinação do MPC. Este aumento de umidade resulta uma diminuição da reidratação e dispersibilidade, menor rendimento durante a secagem, problemas de operação, dificuldades de manuseio e armazenamento. Além disso, a cristalização da lactose no MPC pode causar a reação de escurecimento de Maillard e oxidação da gordura. Para evitar este problema, é necessário pré-cristalizar a lactose como alfa-lactose mono-hidratada, que não é higroscópica, antes da secagem por pulverização. Esse procedimento é essencial para prevenir a deterioração do MPC resultante da cristalização da lactose ou de reações químicas. Além disso, o controle dessa etapa é importante para a obtenção de um pó especificado e reproduzível, em termos de tamanho e grau de cristalização. Existem inúmeros relatórios sobre a reologia de produtos à base de leite, incluindo leite cru e produtos acidificados, como iogurte e queijo. No entanto, existem poucos estudos sobre sistemas concentrados. Consequentemente, o objetivo do presente trabalho é revisar os conceitos básicos de cristalização da lactose e reologia do concentrado proteico do leite.

Palavras-chave: Concentrado proteico do leite; Cristalização de lactose; Reologia; Laticínios; Spray dryer; Engenharia de alimentos; Tecnologia de leite e derivados.

\section{Resumen}

El concentrado de proteína de leche (MPC) es una designación comercial para ingredientes lácteos con mayor contenido de proteína y menor contenido de lactosa que la leche desnatada en polvo convencional. La lactosa en su forma amorfa se encuentra en varios polvos lácteos secados por aspersión. La lactosa amorfa es termodinámicamente inestable y puede movilizarse y cristalizar con el tiempo a una temperatura y un contenido de humedad adecuados. La absorción de humedad del aire precede a la cristalización, lo que mejora la cohesión y el apelmazamiento del MPC. Este aumento de humedad da como resultado una mala rehidratación y dispersabilidad, menor rendimiento durante el secado, problemas de operación, dificultades de manipulación y almacenamiento. Además, la cristalización de lactosa en MPC puede causar la reacción de pardeamiento de Maillard y oxidación de grasas. Para evitar este problema, es necesario precristalizar la lactosa como alfa-lactosa monohidrato, que no es higroscópica, antes del secado por pulverización. Dicho procedimiento es esencial para prevenir el deterioro de MPC resultante de la cristalización de lactosa o reacciones químicas. Además, el control de este paso es importante para obtener un polvo específico y reproducible, en términos 
de tamaño y nivel de cristalización. Existen numerosos informes sobre la reología de los productos lácteos, incluida la leche cruda y los productos acidificados como el yogur y el queso. Sin embargo, se han realizado pocos estudios sobre sistemas concentrados. En consecuencia, el objetivo del presente trabajo es revisar conceptos básicos de cristalización de lactosa y reología del concentrado de proteína de leche.

Palabras clave: Concentrado de proteína de leche; Cristalización de lactosa; Reología; Productos lácteos; Spray dryer; Ingeniería de alimentos; Tecnología láctea.

\section{Introduction}

Milk is the secretion of the mammary glands of female mammals, whose natural function is to feed the newborns. From a physicochemical point of view, milk is a homogeneous mixture of various components (lactose, glycerides, proteins, salts, vitamins, and enzymes), some of which are in emulsion (fat and substances associated), some in suspension (caseins associated with mineral salts), and others in true dissolution (lactose, water-soluble vitamins, whey proteins, and salts). Milk protein concentrates (MPCs) contain casein and whey proteins in concentrations ranging from 40 to 89\%. Lactose levels decrease when the protein concentration of MPC increases. The product is used for its nutritional and functional properties. MPCs with a higher protein content provide a clean dairy flavor to food and beverage without adding a significant amount of lactose. Additionally, MPC provides food with many benefits, including water binding, gelling, foaming, emulsification, and heat stability (Havea, 2006; Li et al., 2018).

Lactose is found in an amorphous state in several spray-dried dairy powders. Thermodynamically, amorphous components are unstable and, under sufficient conditions of temperature $(\cong 24 \mathrm{C})$ and moisture content (relative humidity of 37\%), can mobilize and crystallize over time (Roos, 2002). Moisture sorption from the air and the development of liquid bridges between powder particles precede crystallization, increasing the powder's cohesiveness and caking. This results in poor rehydration and dispersibility, lower yield during drying, operational issues, difficulties in handling and storage. In addition, crystallization can cause Maillard browning reaction and fat oxidation (Fitzpatrick et al., 2007). To avoid this problem, it is necessary to pre-crystallize lactose as alpha-lactose monohydrate, which is non-hygroscopic, before spray drying. Such a procedure is essential in controlling the stability of MPC powder and avoiding deterioration resulting from lactose crystallization or chemical reactions. Furthermore, management of this process is required to produce the desired and reproducible powder size and crystallization level (Özkan et al., 2002; Rodier \& Hartel, 2021).

There are various reports on the rheology of milk-based products; however, there is a lack of investigation on concentrated systems. Therefore, there is a need to enhance the knowledge established from academic research, making it suitable for designing an industrial lactose pre-crystallization of MPC. The knowledge acquired from the rheology of reconstituted MPC will provide insight into how lactose crystallization impacts product quality. The ability to predict rheological behavior is crucial for process optimization.

\section{Methodology}

The present work is a literature review from bibliographic research in reliable scientific databases such as Science Direct, Scopus, Wiley Online Library, and Scielo. To search for scientific articles, we used terms such as "lactose," “crystallization,” “milk protein concentrate,” “rheology,” “nucleation,” “mutarotation,” “aggregation,” “kinetics,” “spray-dryer,” and "caking.” Criteria such as articles mostly in English and preferably published between the years 2011 to 2021 were adopted for the selection of the most relevant publications on lactose crystallization in milk protein concentrate. However, it is important to note that although several articles used in this review were published before 2011, they were still included in the study due to their scientific importance, and most of them have more than one hundred citations. Moreover, since the goal of the present literature review is to provide information on dairy products (e.g., lactose and milk protein concentrate), 68\% of the research 
papers included in this work are from the field of dairy technology, whereas 32\% are focused on chemical engineering, especially on the processes of spray drying and crystallization.

\section{Results and Discussion}

\subsection{Lactose}

Lactose was first synthesized in 1971 by Kretchmer, who discovered the lactose's precise molecular structure 300 years after its discovery by Bartoletus in 1633. Lactose is a disaccharide comprising one D-glucose molecule linked to a D-galactose molecule by a beta $(1 \rightarrow 4)$ glycosidic bond. It is found in large amounts in the milk of all mammals, with only a few exceptions, such as sea lions, some seals, and opossums (Jenness \& Holt, 1987; Urashima et al., 2021). The approximate concentration in mammalian milk is between 2.0 and 10\% (Holsinger, 1988). In aqueous solution, lactose molecules are present in two isomeric forms. The asymmetric carbon atom of the number 1 carbon of the glucose moiety results in two anomers, designated as alpha and beta lactose. Refer to Figure 1 for the chemical structure of alpha and beta lactose anomers.

Figure 1. Chemical structure of alpha-lactose and beta-lactose.

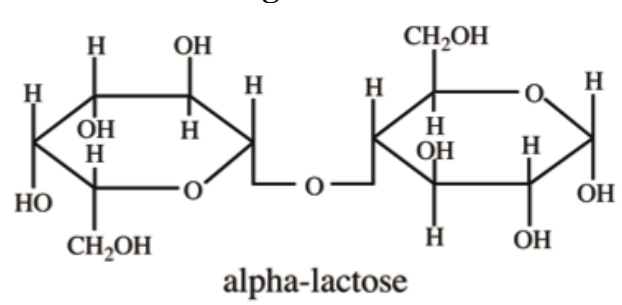

(a)

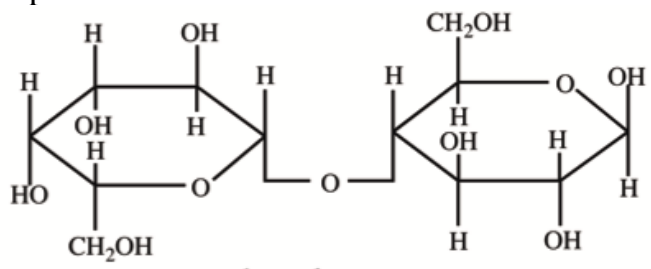

beta-lactose

(b)

Source: Goulart, D. B. (current manuscript).

Lactose exists in three solid forms, alpha-lactose monohydrate, beta-lactose anhydrous, and amorphous lactose. Refer to Figure 2 for the microscopic images of lactose crystals. Alpha-lactose monohydrate is the most common form of lactose used in industry, which is made by crystallizing an aqueous solution below 93.5C. Beta-lactose is formed when crystallization occurs above 93.5C. Amorphous lactose is a non-crystalline form produced during rapid drying. The lactose portion of whey powder is usually in an amorphous state. Amorphous lactose is hygroscopic and readily absorbs water from a humid environment. When sufficient water has been absorbed, the whey powder becomes sticky and cakes together to form a non-flowing product. An anhydrous alpha-lactose crystal may be produced when the water of crystallization is removed by heating the alpha-hydrate above 100C under vacuum (Bronlund \& Paterson, 2004; Batra et al., 2020).

Figure 2. Photomicroscopy (40x magnification) of alpha-lactose monohydrate crystals in milk protein concentrate with a concentration of $46 \%$ total solids, seeded with lactose size of 40 mesh, at different temperatures: (a) 15C, (b) 20C, and (c) 25C.

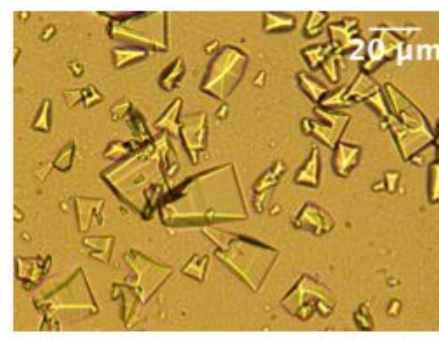

(a)

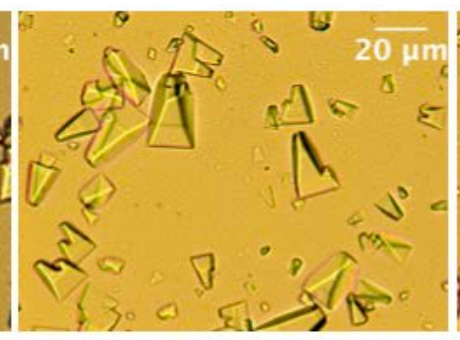

(b)

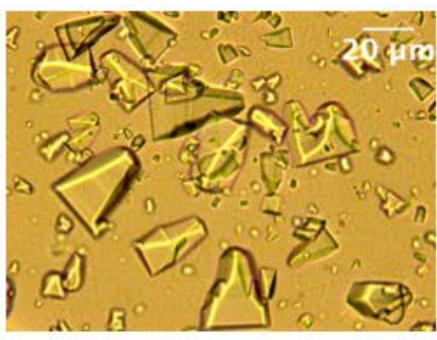

(c)

Source: Goulart and Hartel (2017). 


\subsection{Mutarotation}

Regardless of the lactose form used in preparing a solution, mutarotation alters the alpha form into the beta form and vice-versa until the solution reaches an optical rotation of $+35^{\circ}$ at equilibrium. At neutral $\mathrm{pH}$ and room temperature, this is equivalent to $37.3 \%$ alpha-lactose and $62.7 \%$ beta-lactose, or a ratio of 1.68 beta to alpha forms (Nickerson, 1954). Refer to Figure 3 for the two reactions involved in the mutarotational equilibrium between alpha and beta-lactose. Both are first-order reactions. The equilibrium ratio [beta]/[alpha] is denoted by $R$, where $R=k 1 / k 2$. The rate constant for the mutarotation reaction is $k=k 1+k 2$ (Walstra et al., 1999).

Figure 3. Mutarotational equilibrium between alpha-lactose and beta-lactose.

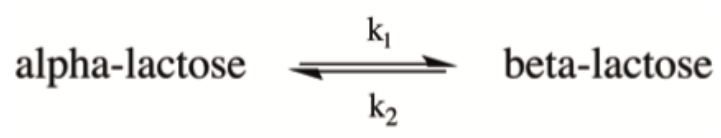

Source: Goulart, D. B. (current manuscript).

The mutarotation of lactose, or sugars in general, is influenced by many factors (Gutiérrez-Méndez, 2020). The exact time to reach equilibrium between the two forms is dependent on temperature, $\mathrm{pH}$, and the presence of impurities. Usually, typical equilibrium times are reported to fall within the 3.5 to 6.5-hour range. The equilibrium is reached in a few minutes at 70C and after some hours at 20C (Harper, 1992; Jawad et al., 2012). The mutarotation rate is slow at low temperatures and increases 2.8 times with every 10C rise in temperature, becoming almost instantaneous at about 75C. At roughly $\mathrm{pH} 5.0$, the rate of mutarotation is at a minimum, increasing with variations on either side of this value (Gänzle et al., 2008; Chen et al., 2020).

Because the velocity of lactose mutarotation regulates crystallization rate, the possibility that a range of chemicals may increase the speed seemed worth investigating. Several researchers have studied the influence of sucrose on lactose mutarotation. Troy and Sharp (1930) reported that sucrose had little or no effect on mutarotation. However, their study was limited to a maximum sucrose concentration of $40 \%$ and a maximum temperature of 25C. Patel and Nickerson determined the kinetics of lactose mutarotation in the presence of sucrose at 25, 30, and 35C (Patel \& Nickerson, 1970). The rate of mutarotation decreased slightly with sucrose addition up to $40 \%$ and significantly reduced after that. Increasing sucrose from 30 to $60 \mathrm{~g}$ per $100 \mathrm{~mL}$ solution decreased the velocity constant by 1.8 to 1.9 , independent of the lactose concentration. Another investigation revealed that impurities like milk salts increased the rate of mutarotation by a factor of 2 compared to a solution in water (Tan, 2009). Lefort and colleagues (2006) measured the mutarotation reaction of lactose in the solid-state in real-time in situ. The mutarotation occurred in the amorphous but not in the crystalline state, suggesting that physical state significantly impacts mutarotation.

\subsection{Solubility}

Although lactose's solubility is low compared with other disaccharides, the effect of temperature on solubility is more noticeable (Sienkiewicz and Riedel, 1990; Choscz et al., 2019). The solubilities of alpha and beta-lactose are vastly different from each other. Alpha-lactose is more soluble above $93.5 \mathrm{C}(70 \mathrm{~g} / \mathrm{L}$ at $20 \mathrm{C})$, whereas beta-lactose is significantly more soluble at ambient conditions (500g/L at 20C) (Gänzle et al., 2008; McSweeney \& Fox, 2009). When alpha-lactose monohydrate is placed in water more than the amount capable of going into solution, a definite amount (about $7 \mathrm{~g}$ per 100g, 15C) dissolves immediately. This initial solubility is the alpha form's true solubility. Solubility rises with time due to mutarotation. The solution becomes unsaturated with regard to alpha as the alpha form is transformed to beta, and more alpha monohydrate dissolves. The process is repeated until a final equilibrium is achieved and a final solubility is determined (about 17g per 100g, 15C) (Holsinger, 1988). When this equilibrium is established, there is no further dissolution, and the solution has reached its point of saturation. Under similar conditions, beta-lactose shows considerably higher initial solubility in water (about 50g per 100g, 15C) (Hunziker 
\& Nissen, 1926). The specific optical rotation of alpha-lactose is $+89^{\circ}$, whereas the specific optical rotation of beta-lactose is $+35^{\circ}$ (McSweeney and Fox, 2009).

Lactose contains both primary and secondary alcohol groups, which largely account for its high solubility in water and lack of solubility in organic solvents (McSweeney \& Fox, 1958; Enayati et al., 2018). Hunziker and Nissen (1926) measured lactose solubility in the presence of sucrose and milk colloids compared to lactose solubility in water. Various solutions were prepared in which lactose was dissolved in water, skim milk, whole milk, and sucrose solutions. The solubility of lactose in milk was similar to that in aqueous solutions, but sucrose decreased the lactose solubility somewhat. This decrease in lactose solubility became more significant as the sucrose concentration increased, from about one-twentieth to one-sixth of the lactose solubility found in pure water. The colloids in milk did not influence the solubility of lactose.

Sugars usually show increased solubility in the presence of some salts, probably due to the formation of compounds in solutions (McSweeney and Fox 1958). Nickerson studied the solubility of lactose in salt solutions and concluded that lactose is more soluble in solutions of calcium chloride or of calcium nitrate than in pure water (Nickerson, 1954). The increased solubility of lactose in calcium chloride solutions was due to the formation of a lactose and calcium chloride molecular compound, alphalactose $\mathrm{CaCl}_{2} .7 \mathrm{H}_{2} \mathrm{O}$.

\subsection{Mechanisms of Lactose Crystallization}

Crystallization was first explored scientifically only in the second part of the twentieth century. The processes of nucleus formation, crystal development, aggregation, ripening, and crystal breaking are still poorly understood. Crystallization is one of the oldest and most essential procedures in industrial chemistry and food engineering, and it is frequently used for the purification, separation, and creation of high-quality crystals. It is a practical and convenient method to obtain a concentrated substance in pure form. Crystallization has two phases, including nucleation and nucleus's growth. Cooling a hot concentrated solution without agitation can generate solutions with more dissolved solids than equilibrium saturation. Such solutions are referred to as supersaturated solutions. Crystallization can only occur in a supersaturated solution. A solution that is supersaturated is not in equilibrium. The solution crystallizes to relieve the supersaturation and reach equilibrium. Previous studies, particularly at the Cooperative Condensfabriek Friesland in the Netherlands, focused on the processes and dynamics of lactose crystal formation and growth in considerable detail (Van Krevel \& Michaels, 1965; Van Krevel, 1969).

Lactose crystals have a variety of shapes, depending on how crystallization occurs. The most common shapes are prism, tomahawk, and pyramid (Herrington, 1934; O’Donoghue et al., 2019). The formation of a prism is stimulated by high supersaturation, which forces rapid crystallization. As supersaturation decreases, the prevalent crystal form shifts to diamondshaped plates, then to pyramids, and finally to tomahawk-shaped crystals showing many faces (Nickerson, 1979; Holsinger, 1988). When crystallized slowly from a solution, alpha-lactose monohydrate has a tomahawk crystal shape, while beta-lactose has an uneven-sided diamond crystal shape (Listiohadi, 2005). Figure 4 depicts the effect of different supersaturation levels on the morphology of lactose crystals. 
Figure 4. Shape of alpha-lactose monohydrate crystals grown at different supersaturations.

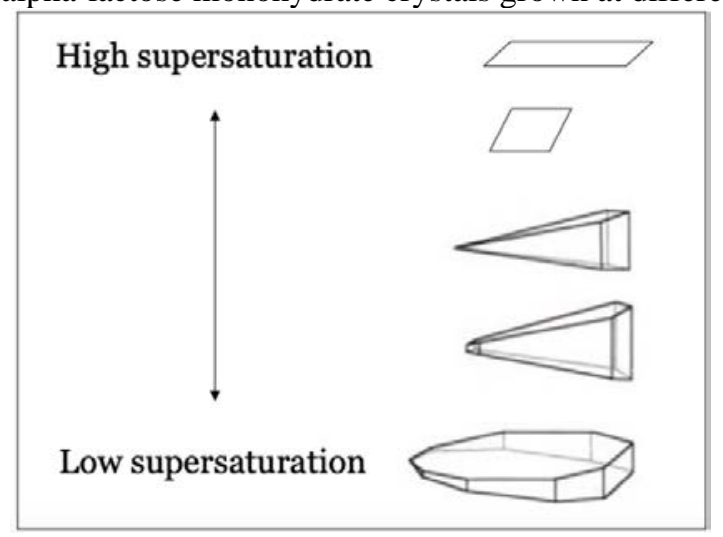

Source: Goulart, D. B. (current manuscript).

Among the most common expressions of supersaturation are the concentration driving force, $\Delta c$ (Eq. (1)), the supersaturation ratio, $S$ (Eq. (2)), and the absolute or relative supersaturation, $\sigma$ (Eq. (3)) (Mullin, 2001). These quantities are defined by the following:

Eq. (1) $\Delta c=c-c *$

Eq. (2) $S=\frac{c}{c *}$

Eq. (3) $\sigma=\frac{\Delta c}{c *}=S-1$

Here, $c$ is the solution concentration, and $c^{*}$ is the equilibrium saturation at the given temperature. Lactose crystallization is a critical separation process in the production of MPC. The size and bulk of crystals impact the next phase of spray drying and the quality of the dairy powder. It is important to control crystallization kinetics and the quality of lactose crystals. Understanding how milk components impact kinetics is essential in the development, analysis, and control of lactose crystallization.

\subsubsection{Nucleation}

Nucleation is the step that initiates the crystallization process, which involves the formation of crystals from a supersaturated solution. The nuclei grow based on the supersaturation level, which, along with temperature, are the key variables determining the nucleation rate (McLeod et al., 2011; Pandalaneni and Amamcharla 2018). Primary and secondary nucleation are the two types of nucleation. Primary nucleation can take place in the presence (heterogeneous) or lack (homogeneous) of particles that help form stable clusters. Heterogeneous nucleation is the major source of initial nuclei formation in lactose refining. This is because lactose refining occurs at a low supersaturation, which inhibits the occurrence of homogeneous nucleation. At lower supersaturations, the energy available in the supersaturated solution is insufficient to promote the production of nuclei through homogeneous nucleation (Shi et al., 1989). Figure 5 depicts the types of nucleation. 
Figure 5. Scheme showing the types of nucleation.

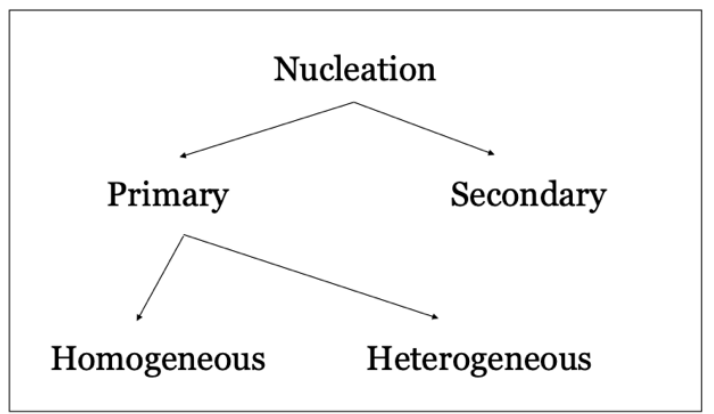

Source: Goulart, D. B. (current manuscript).

The presence of lactose seed crystals is necessary for secondary (or contact) nucleation to occur. Secondary nucleation occurs at lower levels of supersaturation (1.6 times the solubility limit) than primary nucleation (2.1 times the solubility limit) (McLeod, 2011). This occurs because nucleation is catalyzed by the existing crystals, allowing the process to occur at a lower supersaturation than spontaneous nucleation (Levi and Kotrla, 1997; Xu et al., 2020). When crystals in a stirred suspension collide with each other, the vessel walls or the impeller, contact nuclei may form as a result of the disruption of the growth layer that separates the solution phase from the lattice structure or as a result of small crystal fragments dislocated from the contact surface (Shi et al., 1989). Goulart and Hartel (2017) investigated the impact of lactose crystallization in MPC and found that because secondary nucleation followed the growth of primary lactose crystals, several tiny crystals with various morphologies were formed in addition to the pre-existing crystals with tomahawk shape.

Secondary nucleation may be prevented by maintaining the crystallization process within the metastable region during batch lactose refining (McLeod et al., 2011; Briuglia et al., 2019). Secondary nucleation in crystallizers is thought to be caused by crystal-agitator interactions. The likelihood of such a contact is related to the rotational speed of the agitator (McLeod et al., 2011). Another aspect to consider is the hardness of the contacting bodies: a metal impeller provides a greater nucleation rate than one covered with a soft material like polyethylene (Shah et al., 1973). Figure 6 depicts an anchor impeller agitator used during a batch lactose crystallization process.

Figure 6. Anchor impeller agitator used during the lactose crystallization process.

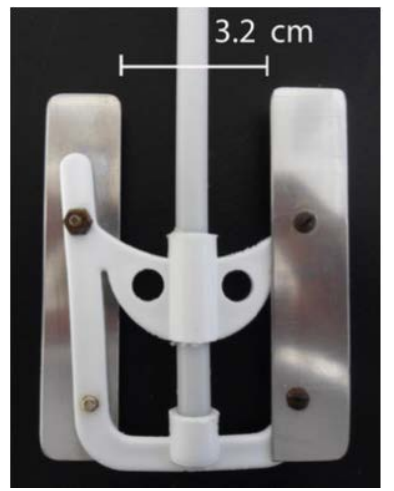

Source: Goulart, D. B. (current manuscript).

The main concepts presented in Figure 7 are summarized by Wong and collaborators (2011) as:

(i) In the undersaturated zone, neither nucleation nor growth can occur;

(ii) A crystal can develop in both the metastable and labile zones;

(iii) In the labile zone, spontaneous nucleation can occur without the addition of seeding material; 
(iv) The metastable zone can be divided into upper and lower metastable limits in a seeded crystallization process. The formation of small nuclei by secondary nucleation is reduced in the upper area, whereas seed crystal development is promoted. When the seed crystal is introduced at the beginning of the forced crystallization line, mass crystallization (the production of tiny crystal centers) is boosted during cooling crystallization in the lower region, and further cooling is maintained in the lower metastable area; and

(v) Crystallization can only take place in the metastable zone by seeding with lactose or with substances containing lactose.

Figure 7. Lactose supersolubility diagram.

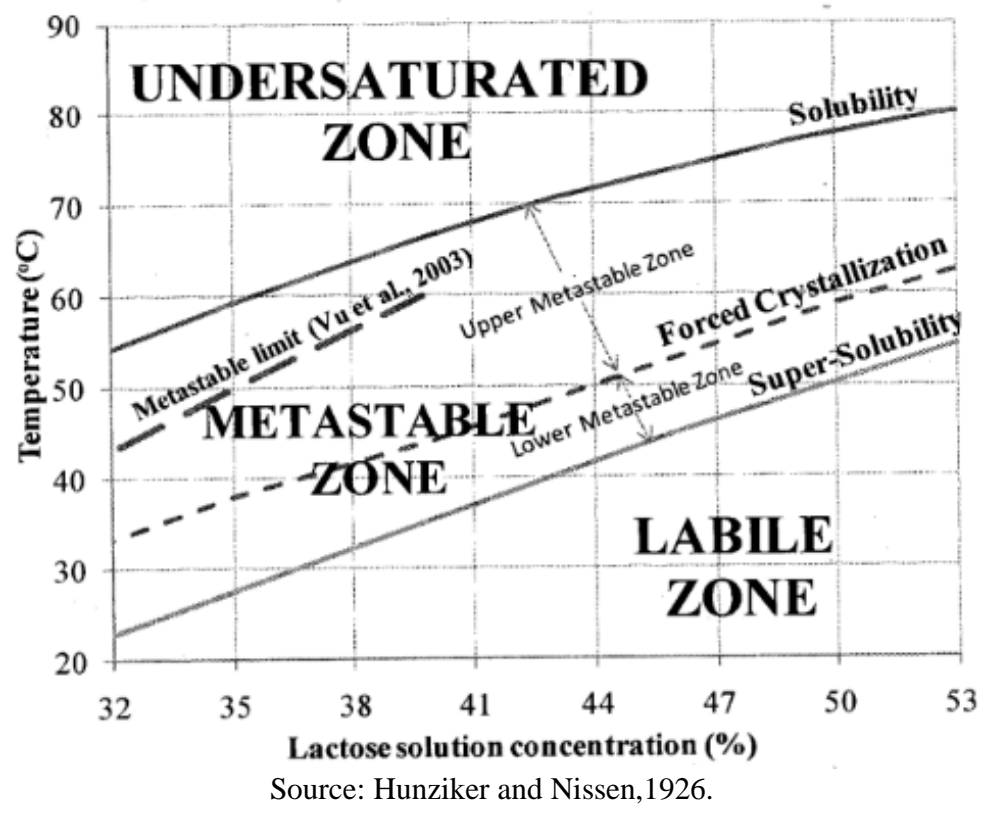

Wong and colleagues (2011) conducted an investigation whose aim was to refine the metastable limit (ML) for lactose crystallization, making it suitable for designing an industrial operation. To determine the effect of agitation speed on the ML, the experiments were conducted at three different agitation speeds (942, 1674, and $2512 \mathrm{rpm}$ ). The stirrer was initiated and lactose seeds $(0.1 \mathrm{~g}$ of seeds between 90 and $250 \mu \mathrm{m})$ were added once the initial solubility temperature was stable. The temperature of the initial nuclei detection was shown to be independent of the agitation speed. Furthermore, when the agitation speed rose, the extent of secondary nucleation increased rapidly following the formation of the initial nuclei. Importantly, these findings suggest that lactose crystallization should operate at a minimal agitation rate in the upper ML to avoid secondary nucleation and promote crystal growth effectively.

\subsubsection{Crystal Growth}

As soon as stable nuclei have been formed in a supersaturated or supercooled system, they begin to grow larger by adding solute molecules from the supersaturated solution (Mullin, 2001). Crystals are solids in which the atoms or molecules are arranged in a periodic repeating pattern that extends in three dimensions (Myerson \& Ginde, 2002; Moeck, 2018). The three processes of crystal growth are (1) mass transfer from the bulk to the crystal surface, (2) surface reaction and integration, and (3) transmission of latent heat away from the developing crystals (Matusevich \& Blinova, 1964; May et al., 2020).

There are several proposed crystal growth theories. The surface energy theories claim that a developing crystal assumes the form with the lowest surface energy. However, this theory does not explain how supersaturation affects crystal growth rate. According to diffusion theories, the rate at which matter is deposited on a crystal face is proportional to the concentration difference between the point of deposition and the bulk of the solution (Mullin, 2001; Galenko \& Ankudinov, 2019). The 
adsorption-layer theories arose from Volmer's proposal that crystal growth is a discontinuous process involving layer-by-layer adsorption on the crystal surface. In this thermodynamic theory, many crystal layers grow simultaneously, causing hillocks and cavities on the surface when atoms deposit across relatively high layers (Levi \& Kotrla, 1997).

\subsubsection{Aggregation}

Many industrially manufactured crystals show signs of aggregation or intergrowth. This phenomenon usually occurs when rapidly growing crystals contact each other (Levi \& Kotrla, 1997; Mi et al., 2020). Small crystals in the early development phase following nucleus production while those with a significant variation in crystal size tend to develop aggregates (Hunziker \& Nissen, 1926). Furthermore, because crystal clusters often retain impure mother liquor and resist efficient washing, aggregation is frequently suggestive of impurities (Mullin, 2001; Shi et al., 2006). Aggregated crystals are not desirable in lactose refining. They cause entrainment of the mother solution, impairing the centrifugation and washing processes. In a crystalline mass, aggregates spoil the product's appearance and interfere with its free-flowing nature (Shi et al., 2006; Kawashima, 2019). The degree of aggregation is highly dependent on the crystallization mechanism. Investigators found that aggregation decreased with increased intensity of agitation, average size, and amounts of primary crystals (Matusevich \& Blinova, 1964).

\subsubsection{Growth rate dispersion}

The concept of growth rate dispersion is based on the observation that crystals of the same size and material subjected to similar supersaturation, temperature, and hydrodynamic conditions do not always grow simultaneously (Nanev, 2000; Myerson \& Ginde, 2002). Explanations of growth rate dispersion have suggested different theories. Surface energy theories are founded on the idea that a developing crystal assumes a form with the least surface energy (Chernov, 1989; Zhang et al., 2018). Diffusion theories state that matter is continually deposited on a crystal face at a rate proportionate to the concentration difference between the deposition point and the bulk of the solution (Mullin, 2001). The adsorption-layer theories arose from Volmer's notion that crystal development is a discontinuation process involving layer-by-layer adsorption on the crystal surface (Beuselinck, 1998).

Variations in the position or density of screw dislocations have been found to produce substantial changes in the crystal growth rate. Crystal collisions with the impeller, walls and each other can cause dislocation damage and, as a result, changes in the crystal growth rate. This is especially true for secondary nuclei, which can have a wide range of dislocation densities. Furthermore, the imperfect nature of the crystal development process may cause alterations in the crystal faces' dislocations (Myerson \& Ginde, 2002; Olson et al., 2018).

In a batch crystallizer, crystallization is induced either by nucleation of the solution or by the addition of seeds. Even though the crystals grow in similar conditions, the actual growth rates of individual crystals may vary and are dependent on various factors. The factors include the hydrodynamic characteristics of the crystal-solution system, the interactions of the crystal with the stirrer and other crystals in the crystallizer, the local temperature at the crystal surface, the type of nucleation that preceded the growth step, and the number and the types of dislocations present on the crystal surface (Beuselinck, 1998). However, when studying a population of crystals grown under similar conditions, general growth characteristics of the entire population must be characterized. For this reason, crystal growth studies for batch crystallization experiments are based on the change in crystal size distributions (CSD) for the population (Marsh, 1988; Ghadipasha et al., 2018; Teixeira et al., 2020).

\subsection{Commercial Lactose Crystallization}

Although lactose can be synthesized, it is obtained mainly from milk whey, a by-product of cheese and butter, purified to remove fats, proteins, vitamins, and minerals. Figure 8 shows a flowchart of lactose production. Crystallization of cheese 
whey or deproteinized whey can be used to produce refined lactose (Harper, 1992; Gutiérrez-Méndez, 2020). Whey is a byproduct of the manufacture of cheese, remaining after milk has been curdled and strained. It is composed of $5 \%$ lactose, $0.7 \%$ protein, and 93\% water and salts (Cuartas-Uribe et al., 2009). Because lactose has a high biological oxygen demand (B.O.D.), its disposal into rivers promotes bacterial growth and oxygen depletion of water. Consequently, it is desirable to extract lactose from whey to reduce the ecological impact. Additionally, recovery of lactose from whey could improve the economics of lactose utilization, as lactose is commonly used in different business, including but not limited to the food, pharmaceutical, and confectionery industries.

Figure 8. Flowchart of lactose production.

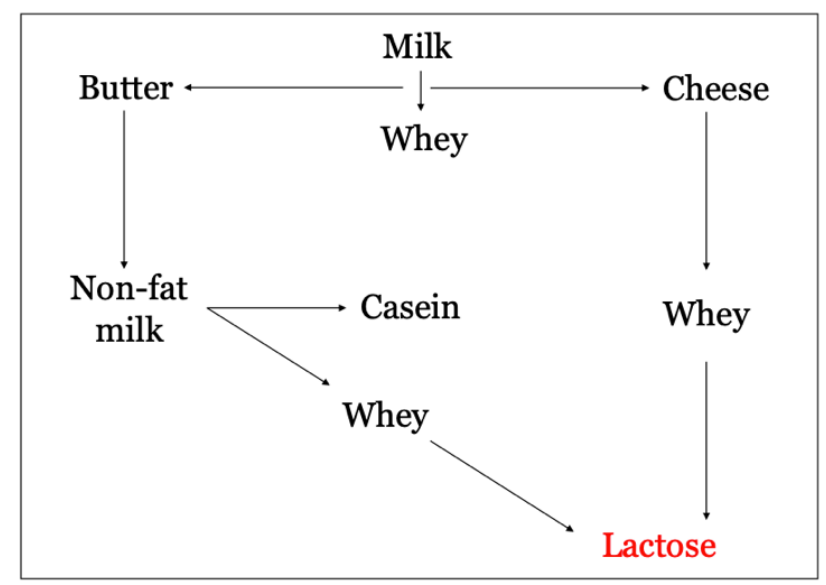

Source: Goulart, D. B. (current manuscript).

The keys to designing and optimizing industrial lactose crystallization include fundamental information, such as the mechanism of lactose crystallization, the concept of crystallizer operation, modeling methodologies, and the effects of whey constituents on the crystallization rate. In order to avoid low-quality MPC due to lactose crystallization after the product is manufactured, it is necessary to pre-crystallize lactose as alpha-lactose monohydrate before spray drying. This process is critical for maintaining MPC powder stability and avoiding degradation due to lactose crystallization or chemical interactions. This stage must also be controlled to obtain specified and reproducible powder, in terms of size and crystallization level.

For the production of industrial lactose, three approaches have been proposed: crystallization from a supersaturated solution, precipitation caused by alkaline earth minerals, and precipitation caused by solvents such as alcohol. The crystallization technique is the most popular of these methods (Harper, 1992). The three main steps in the production of industrial lactose are concentration, crystallization, and purification (McSweeney \& Fox, 2009; Darmali et al., 2019).

Evaporation is typically performed in a falling film evaporator, and it aims to achieve the highest possible concentration (52 to $62 \%$ total solids) under low temperatures (Knipschildt \& Andersen, 1993). When the concentrate reaches its desired concentration, it is fed to a batch crystallization tank where lactose crystals form for 12 to 18 hours (Tan, 2009). A gradual cooling process is performed with a rate of 1.5 to 3.0C per hour, and continuous gentle agitation is provided to prevent crystal sedimentation (Knipschildt \& Andersen, 1993). When the crystallization process is completed, the crystals are separated from the mother liquor through a decanter centrifuge and a washing step to remove traces of impurities. Drying is the final operation performed in a flash dryer with an inlet temperature ranging between 120 to 180C. The water is removed from the crystals, and a small layer of amorphous lactose is created on the surface of the crystals. This amorphous lactose crystallizes in the first stage of a stationary fluid bed. The drying temperature for the first section ranges between 110 to 120C, whereas the second section cools the product with air below 40C. Finally, the crystals are ground to the required size and packaged (McSweeney \& Fox, 2009). 
Spray-dried lactose-rich powders including whey powder, whey permeate powder, and pharmaceutical-grade spraydried lactose have a range of 10 to $15 \%$ amorphous lactose (Smithers \& Augustin, 2013). Before spray drying, these products usually go through a pre-crystallization process. This guarantees that a large amount of the lactose in the spray-dried product (usually $75 \%$ or more) is in the non-hygroscopic alpha-lactose monohydrate form, making it more humidity stable (Darcy \& Buckton, 1998). By pre-crystallization, up to 50-75\% crystallinity may be achieved in whey powder (McSweeney \& Fox, 2009). This technique produces a noncaking, dust-free, and free-flowing product. Because the agglomerates are small, the bulk density is relatively high (Andersen, 2005; Saxena et al., 2021).

\subsection{Industrial Applications of Lactose}

The principles of crystallization and the parameters that influence the formation of lactose crystals have been applied to dairy products to better understand the effects of processing conditions on the quality of lactose-containing dairy products. Lactose is extensively employed as a bulking ingredient in pharmaceutical formulations for human and animal medical products (Miao and Roos, 2005; Hebbink \& Dickhoff, 2019). For medical applications, crystal uniformity, smoothness of the surface, and suitable forms are crucial. Lactose supply and grade have a significant impact on medication delivery. In a dry-powder inhaler application, for example, boosting the elongation ratio of the lactose crystals greatly improved the drug's medical profile.

Lactose is not as sweet as fructose or sucrose. Consequently, its use can be favorable in reducing the overall sweetness profile of confectionery. The low sweetness permits lactose to be added to numerous products such as toppings, icings, and fruit pie fillings to enhance the osmotic pressure, viscosity, or texture without making the product too sweet (Smart et al., 1991). The reduced sweetness of lactose solutions at ambient conditions is about 20\% that of sucrose (Bronlund \& Paterson, 2004). However, the sweetness of lactose in milk is clearly noticeable (Pangborn, 1963). Beta-lactose is sweeter than alpha-lactose, but betalactose is not significantly sweeter than the equilibrium mixtures until the lactose concentration exceeds $7.0 \%$ in solution (Pangborn \& Gee, 1961).

Lactose is a reducing sugar, which means it has an aldehyde group or can form one in solution through isomerism. When heating lactose-containing products under severe conditions, the free amino acid side chains of milk proteins (- $\varepsilon$-amino group of lysine residue) interact with the aldehyde group of lactose's glucose moiety. This nonenzymatic reaction is called Maillard browning and results in the production of flavor and aroma compounds. Although the reaction contributes positively to the flavor and color of some foods, such as crust of bread and deep-fried products, it is an issue in cheese subjected to severe heating. For example, excessive browning or blistering is undesirable in cheeses such as mozzarella (Tan, 2009; Xiang et al., 2021).

\subsection{Milk Protein Concentrate}

MPC is a commercial designation for a group of dairy ingredients with higher protein and lower lactose content as compared to conventional skim milk powder (SMP). A commercial classification of MPC is done according to its protein content, ranging between 42 and 85\% weight/weight (w/w) dry basis. High protein content MPC is known as milk protein isolates (MPI) (Huffman \& Harper, 1999). MPC powders, especially those with more than 70\% protein, have been shown to have low solubilities, which can degrade further with storage at high ambient temperatures, relative humidity, or water activities (Sikand et al., 2011; Fang et al., 2011; Le et al., 2011). Table 1 shows the typical composition of commercially produced milk concentrates. 
Table 1. General composition of different SMP, MPC and MPI.

\begin{tabular}{lcccccc}
\hline Component & $\begin{array}{c}\text { SMP } \\
(\%)\end{array}$ & $\begin{array}{c}\text { MPC 42 } \\
(\%)\end{array}$ & $\begin{array}{c}\text { MPC 56 } \\
(\%)\end{array}$ & $\begin{array}{c}\text { MPC 70 } \\
(\%)\end{array}$ & $\begin{array}{c}\text { MPC 85 } \\
(\%)\end{array}$ & $\begin{array}{c}\text { MPI } \\
(\%)\end{array}$ \\
\hline Protein & 36.0 & 40.6 & 54.4 & 68.3 & 83.1 & 87.1 \\
Lactose & 51.0 & 45.5 & 31.7 & 18.2 & 3.5 & 0.5 \\
Ash & 8.2 & 7.9 & 7.6 & 7.3 & 6.9 & 5.9 \\
Fat & 0.8 & 0.9 & 1.2 & 1.2 & 1.5 & 1.5 \\
Moisture & 5.0 & 5.0 & 5.0 & 5.0 & 5.0 & 5.0 \\
\hline
\end{tabular}

Source: Goulart, D. B. (current manuscript).

The functional and physical properties of MPC 42 and MPC 56 are similar to those of SMP, with the additional benefit of a lower lactose and mineral content. This benefit provides a whiter and blander flavor than SMP, thus making MPC suitable for the formulation of products where flavor and aroma compounds generated by SMP are considered defects (Mistry, 2002). An additional benefit of lower lactose content can include an extension on the shelf life of the powder by preventing potential Maillard or caking reactions (Huffman \& Harper, 1999; Fan et al., 2018). Mistry and Hassan studied the microstructure of MPC and SMP powders produced under identical drying conditions (Figures 9 and 10).

Figure 9. Scanning electron micrograph of MPC 85 showing smooth surface and dents.

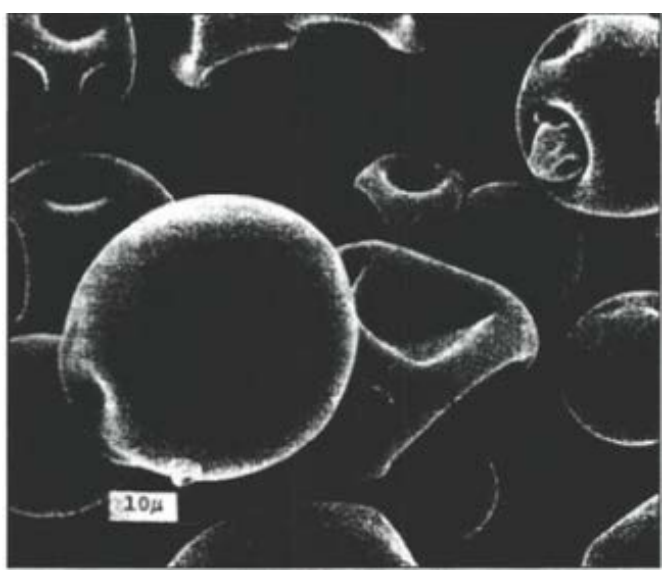

Source: Mistry and Hassan (1991).

Figure 10. Scanning electron micrograph of SMP showing a wrinkle surface.

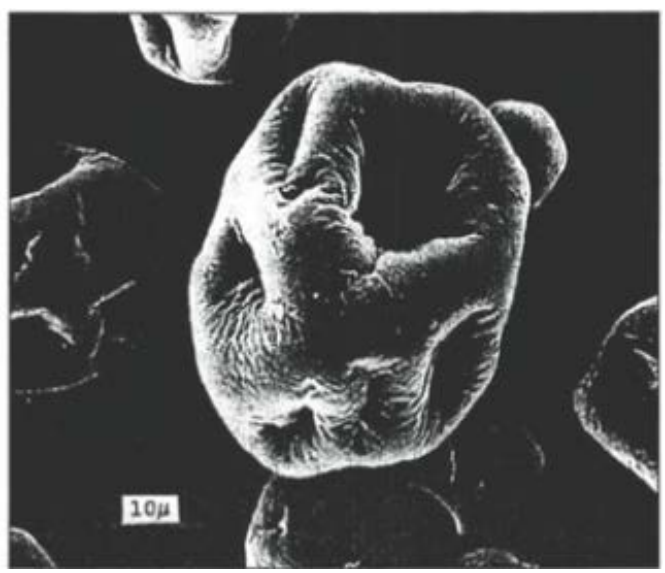

Source: Mistry and Hassan (1991). 
The surface of MPC powder particles (Figure 9) was always smooth with large dents, and the interior of the particles was usually hollow. The SMP particles were also characterized by dents on the surface (Figure 10). However, there was less variation in the size of particles, and, unlike MPC, these particles had a wrinkly surface. The difference in surface morphology between SMP and MPC was probably due to differences in the protein composition; MPC contained $84 \%$, whereas SMP contained 35\% protein (Mistry \& Hassan, 1991).

\subsection{Manufacturing of Milk Protein Concentrate}

In the manufacturing of MPC, the skim milk is pasteurized prior to concentration. This thermal treatment eliminates microorganisms and enzymes that reduce the quality and shelf life of milk. Pasteurization is based on the inactivation of Coxiella burnetti, the most thermally resistant non-spore forming, which is inactivated at $63 \mathrm{C}$ for 30 minutes (low temperature long time treatment) or 72C for 15 seconds (high temperature short time treatment) (Bylund, 1995).

Ultrafiltration is used in the post-pasteurization processing of skim milk (UF). During UF, milk flows across a membrane that separates its components by molecular size. The permeate stream is formed when minerals, lactose, and water pass through the membrane. Because of the higher molecular size of casein (average of around $200 \mathrm{~nm}$ in diameter) and whey proteins, both cannot cross the membrane (Fox \& Brodkorb, 2008). Proteins, lactose, and minerals that do not go into the permeate stream end up in the retentate stream, which is fed into spray dryers to produce MPC. Typical UF membranes are made of dense polymers with pores of molecular dimensions (Edgar \& Axel, 1998; Bildyukevich et al., 2020).

Diafiltration (DF) is a processing aid method performed in combination with UF. DF is used for the production of MPC with protein content greater than $65 \%$. During DF, substances at the ionic level are separated from the colloidal suspension through diffusion across membranes by adding water. The incorporation of water dissolves micro-molecules from retentate, which later permeate through the membrane. Larger molecules (macro-molecules) are maintained in the retentate (Gelter et al., 1996). Once the retentate has reached the desirable concentration, it is subjected to heat treatment to inhibit any potential growth of microorganisms and spores that could jeopardize the final product's quality. This process involves a direct injection system in which steam is injected into the retentate and then flash-cooled, with minimal heat-induced alteration of the product (Gelter $e t$ al., 1996; Gavazzi-April et al., 2018).

Further processing of thermally treated retentate consists in increasing its concentration by water removal. A multiple effect falling film evaporator, in which the water from retentate is evaporated under decreased pressure, is commonly used to produce a concentrate ranging from 32 to 35\% total solids (Gelter et al., 1996; Zhang et al., 2018). The viscosity of the concentrate limits the degree of concentration of the skim milk. Drying is the final processing step before packaging. This practice is normally performed in a spray drying tower, which is part of a multi-stage drying system. The principle of spray drying is created by atomizing a highly dispersed liquid state in a high-temperature gas zone, followed by rapid evaporation and drying of the droplets.

The droplet size is an important parameter because it directly influences the sizes of MPC particles. The same size of the droplet will give the same size of the powder. Higher viscosity makes the fluid more resistant to agitation, preventing it from breaking up and resulting in larger average droplet sizes. Large droplets take longer to dry because their surface area to volume ratio is smaller, impacting the final powder's properties. Common issues are poor solubility, change in functionality, a high moisture level, and the possibility of burnt particles. Furthermore, the large droplets easily foul the spray dryer, leading to short runtimes (Schuck et al., 2005; O'Sullivan et al., 2019). The viscosity of skim milk concentrate should not exceed 100 centipoises at 40C measured on the feed to be atomized (Morrison, 2001). Figure 11 represents the relationship between viscosity and droplet size during atomization. 
Figure 11. Relationship between viscosity and droplet size during atomization.

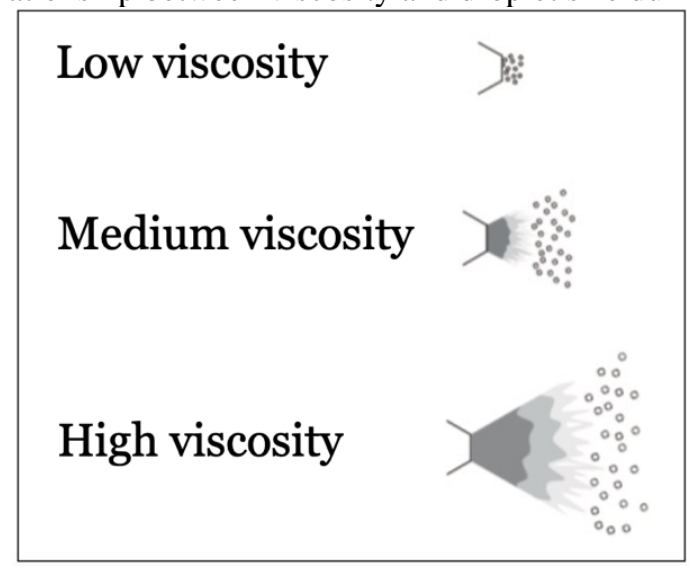

Source: Goulart, D. B. (current manuscript).

Further drying and cooling of particles are obtained by using a two-section vibratory fluidized bed. Within the first section, the particles are layered in a sheet of appropriate thickness as determined by the ability of a vertical flow of hot air to pass through the sheet. The vibratory mechanism transports the product from the first section to the cooling section as the hot air continues to decrease the moisture of the particles by diffusion. The product is treated with dehumidified cool air in the cooling section, which establishes the final moisture content and a temperature below 40C before packing. Sieving the product is indispensable before product packaging. At this step, particles and agglomerates capable of passing through screens proceed to be packaged while large agglomerates are returned to the beginning of the cooling fluidized bed to be broken up by the system's vibrations (Edgar \& Axel, 1998).

\subsection{Applications of Milk Protein Concentrate}

Because of their functional, sensory, and nutritional qualities, MPCs are used in various products, including yogurt, cheese, reduced lactose drinks, and medical nutrition products (Agarwal, 2015; Zhang et al., 2020). The type of MPC used is determined on the application and formulation. MPCs with lower protein content are usually utilized as cheese additives, while MPCs with a higher protein concentration are employed in beverages. MPCs with a greater protein concentration provide food and beverages with a clean dairy flavor without adding a significant amount of lactose. MPCs play an important role in adding minerals to formulations, including calcium, magnesium, and phosphorus. Interestingly, MPCs are multifunctional dairy products that provide important benefits to food, such as water binding, gelling, foaming, emulsification, and heat stability (Huffman \& Harper, 1999).

Cheese milk standardization with MPC has beneficial impacts on the final product. Benefits of cheese milk fortification with MPC include increased production yield for cheeses such as regular and reduced-fat cheddar, mozzarella, and feta cheese. Higher production yields are related to higher total solids recovery, casein, and fat during the manufacturing process (Smart et al., 1991; Li et al., 2020). Rehman and collaborators (2003) reported a 25\% higher total solids recovery with MPC standardized cheese milk than conventional cheesemaking practice, increasing yield from 7.5 to 18\% for reduced-fat cheddar cheese. Other investigators reported a higher fat recovery as the level of protein fortification in cheese milk increased from 3.3 to $4.0 \%$ with the incorporation of MPC (Fox \& Brodkorb, 2008). Due to the low lactose content of MPC, further benefits of cheese milk standardization include a reduction in the volume of whey stream.

Nonfat yogurt is associated with high syneresis, a weak body, and low total solids. To control these defects, hydrocolloids, starches, and SMP are used to increase the total solids content in the finished product (Mistry \& Hassan, 1991; Nikitina et al., 2019). When compared to most stabilizers, MPC as a component in the formulation provides better results in enhancing the gel strength and minimizing the syneresis of yogurt. The gel's strength is concentration dependent and is associated 
with the casein protein. Caseins are good water binders because they form huge micellar chains. As a result of the use of MPC, microstructural pores in gel networks are reduced, decreasing the defects of nonfat yogurt.

Ice cream quality can be enhanced by increasing the nonfat milk total solids by incorporating SMP. However, the use of SMP in ice cream is restricted to low concentrations due to off-flavors and increased lactose content in the finished product (Edgar \& Axel, 1998). Of note, if the lactose concentration is too high, it crystallizes, producing a defect known as sandiness. This defect can be avoided by partially substituting SMP with MPC. MPC increases viscosity and shape retention while decreasing the melting rate of ice cream (Alvarez et al., 2005; Abbas Syed, 2018). The specific size of lactose crystal necessary to cause sandiness varies according to different investigations. Walstra and collaborators (2001) found that lactose crystals must be smaller than $10 \mu \mathrm{m}$ to avoid aggregation and the appearance of sandiness in dairy products. Similarly, Hunziker (1934) suggested that lactose crystals in condensed milk should not surpass $10 \mu \mathrm{m}$. According to Holsinger (1997), lactose crystals must be larger than $16 \mu \mathrm{m}$ to achieve a sandy texture. Nickerson (1962) stated that lactose crystals should be greater than $14 \mu \mathrm{m}$ to produce a sandy texture in the manufacture of ice.

\subsection{Viscosity of Milk Protein Concentrate}

Viscosity is a measure of the internal resistance of a medium to flow. Viscosity may be defined by Eq. (4) (Hiemenz \& Rajagopalan, 1997).

Eq. (4) $\frac{F}{A}=\eta\left(\frac{d v}{d x}\right)$

Where, $\eta$ : coefficient of viscosity (mPa.s),

F: force (dynes) necessary to maintain a velocity gradient between two parallel planes separated by unit distance on a surface $A\left(\mathrm{~cm}^{2}\right)$, and

$(d v / d x)$ : velocity gradient perpendicular to the plane $\left(\sec ^{-1}\right)$.

Usually, $(F / A)$ is expressed as shear stress, $\sigma$, and velocity gradient $(d v / d x)$ is expressed as shear rate, $\gamma$. The unit of viscosity, poise, is defined as the force in dyne.s/ $\mathrm{cm}^{2}$ required to maintain a relative velocity of $1 \mathrm{~cm} / \mathrm{sec}$ between two parallel planes $1 \mathrm{~cm}$ apart. The unit commonly used for milk is the centipoise (cP, 10-2 Poise) (Mezger, 2006).

Fluids can be classified as "Newtonian" if the viscosity coefficient $\eta$ depends only on temperature and pressure and is independent of shear rate. This phenomenon has been seen in gases and homogenous, nonpolymeric liquids such as water and milk (Mezger, 2006; Azarnoosh \& Hassanipour, 2021). Many colloidal dispersions and macromolecular polymer solutions, on the other hand, deviate significantly from Newtonian behavior, with shear rate controlled by shear stress (plasticity), shear duration (thixotropy), or both. These are called "non-Newtonian" fluids. Many such materials also exhibit hysteresis, which means that the viscosity at a given shear rate changes as the shear rate varies. When the viscosity coefficient $\eta$ decreases with increasing shear rate, pseudoplastic behavior occurs, whereas dilatant or shear thickening behavior happens when the viscosity coefficient $\eta$ rises with rising shear rate (Sherbon, 1988).

\subsubsection{Power-Law and the Herschel-Bulkley Models}

The two most commonly used equations for characterizing non-Newtonian fluid foods are the Power-Law or Ostwald-de Waele model (Eq. (5)) and the Herschel-Bulkley model (Eq. (6)) (Sherbon, 1988).

Eq. (5) $\sigma=k \cdot \gamma^{n}$

Eq. (6) $\sigma=\sigma_{0}+k \cdot \gamma^{n}$

Where, $\sigma_{0}$ : yield stress $\left(\right.$ dyne $/ \mathrm{cm}^{2}$ ), 


\section{$k$ : consistency index (dyne $\left.\mathrm{s}^{\mathrm{n}} / \mathrm{cm}^{2}\right)$, and \\ $n$ : flow behavior index (dimensionless).}

The Power-Law model describes viscosity with a function that is proportional to some power of the shear rate. This model can describe a Newtonian fluid when $n=1$. The Herschel-Bulkley model represents fluids that exhibit yield stress, in which the fluid will not flow unless a stress exceeding the yield stress is applied (Bylund, 1995; Taibi \& Messelmi, 2018). When doing rheological measurements, it is critical to maintain a consistent temperature. Unless particular fluid components undergo chemical changes at certain temperatures, the flow behavior index, $n$, generally remains constant with temperature variation. The viscosity and consistency index, on the other hand, are strongly influenced by temperature (Toledo, 1991; Peleg, 2018; Ho et al., 2019).

\subsubsection{Factors Influencing the Viscosity of Milk Protein Concentrate}

The viscosity of milk concentrate has a significant impact on the final product's quality. Understanding the effects of variables on the viscosity of milk concentrate is important for optimizing MPC processing and quality. The viscosity of milk concentrate is influenced by many factors, including the composition of the milk concentrate, the temperature, and the solids content (Mistry, 2002). The protein (P) level in proportion to lactose (L) is critical in determining the viscosity of milk concentrate. The concentrate has a high viscosity when the P: $\mathrm{L}$ ratio is high. To overcome this issue, lactose can be added to milk concentrate to adjust the P:L ratio. Higher fat and lactose content results in reduced viscosity, whereas higher protein concentration results in higher viscosity (Mistry, 2002).

The viscosity of MPC increases exponentially with increasing total solids (TS), in the range of 44 to 50\% TS (Hayashi \& Kudo, 1989; Bista et al., 2020). At high concentrations (above 40\% TS), even a slight increase in concentration results in a significant increase in viscosity (Bienvenue et al., 2003). The first impact of raising the TS content is that the particles' contribution to the total force required to shear the solution increases as the number of particles increases (Bloore \& Boag, 1981). This might be due to an increase in the concentrate's total solids volume fraction. The sum of the volume fractions of the soluble components, mostly lactose, and the insoluble components, both colloidal (casein and whey proteins) and emulsified fat can be termed the volume fraction of milk solids (Snoeren et al., 1982).

Concentration invariably increases the ionic strength and decreases the $\mathrm{pH}$ (Bienvenue et al., 2003). A reduction in $\mathrm{pH}$ can cause micelle electrostatic repulsions to diminish, resulting in weak flocs and an increase in viscosity (Bienvenue et al., 2003; Ho et al., 2018). Furthermore, as particles are concentrated, they are driven closer together, increasing likelihood of aggregation formation. Aggregates lead to three important physical effects: (1) an increase in the apparent volume of the dispersed phase due to the occlusion of continuous phase trapped inside the aggregates, (2) formation of irregular-shaped particles, which tend to increase hydrodynamic resistance to motion, and (3) induction of shear dependence of the viscosity profile because the aggregate structure can be disturbed by strong shear and the irregular-shaped particles tend to align in the direction of flow (Cheng, 1987; Walstra et al., 1999). Even if no aggregation occurs, apparent viscosity rises as the number of particles increases.

The viscosity of milk concentrate decreases as the temperature rises. Heating milk concentrate over 70C causes denaturation of whey proteins, which has a substantial impact on viscosity. Denatured whey proteins bind to casein micelles, causing an increase in micelle size and a shift in micelle-micelle interactions, which raises viscosity. Snoeren and collaborators (1982) found that the viscosity of skim milk concentrates increased in direct proportion to the intensity of the preheat treatment (95C for 5 minutes $>85 \mathrm{C}$ for 1 minute $>70 \mathrm{C}$ for 10 seconds), which was attributed to increased protein voluminosity caused by whey protein denaturation. 


\section{Final Considerations}

The properties of dehydrated dairy products are influenced by factors that involve the operating conditions of the equipment, the characteristics of the raw material, and the storage conditions. Improving the quality of dehydrated dairy products, which is governed by time and temperature history, involves a greater understanding of the process through physical-chemical, thermodynamic, and kinetic approaches. High temperatures used during drying, in association with the residual water in the final drying stages, produce stickiness, aggregation of colloidal particles, and adhesion of powdered whey to the equipment. Properties including flowability, storage stability, and solubilization are intrinsically dependent on the mode and intensity of chemical interactions between water and other constituents in dehydrated dairy products. For future works, the impact of milk proteins on lactose crystallization in MPC might be an interesting field for further investigation. A better understanding of why and how milk proteins influence lactose crystallization in MPC could improve the process of pre-crystallization and product quality. There have been many types of research on the influence of milk proteins on lactose crystallization, but most of them used water or cheese whey as the crystallization environment. Given the difficulty in dealing with high viscosity concentrate, different methods may be appropriate to facilitate the sample manipulation. Additionally, the kinetics study of lactose dissolution at higher temperatures to simulate what happens in an industrial spray dryer more closely would be an important area for future research.

\section{References}

Abbas Syed, Q. (2018). Effects of Different Ingredients on Texture of Ice Cream. Journal of Nutritional Health \& Food Engineering, 8(6). https://doi.org/10.15406/jnhfe.2018.08.00305

Agarwal, S., Beausire, R., Patel, S., \& Patel, H. (2015). Innovative Uses of Milk Protein Concentrates in Product Development. Journal of Food Science, 80(S1), A23-A29. https://doi.org/10.1111/1750-3841.12807

Alvarez, V. B., Wolters, C. L., Vodovotz, Y., \& Ji, T. (2005). Physical Properties of Ice Cream Containing Milk Protein Concentrates. Journal of Dairy Science, 88(3), 862-871. https://doi.org/10.3168/jds.S0022-0302(05)72752-1

Andersen, G. (2005). The Anhydro Paraflash Process for Production of Whey and Permeate Powder. Innovations in Food Technology, $27,20-23$.

Azarnoosh, J., \& Hassanipour, F. (2021). Fluid-Structure Interaction Modeling of Lactating Breast: Newtonian vs. Non Newtonian Milk. Journal of Biomechanics, 124, 110500. https://doi.org/10.1016/j.jbiomech.2021.110500

Batra, A., Desai, D., \& Serajuddin, A. T. M. (2020). Conversion of Alpha-Lactose Monohydrate to Anhydrous Form with Superior Tabletability by Twin-Screw Extrusion at Elevated Temperature. International Journal of Pharmaceutics, 588, 119790. https://doi.org/10.1016/j.ijpharm.2020.119790

Beuselinck, L., Govers, G., Poesen, J., Degraer, G., \& Froyen, L. (1998). Grain-Size Analysis by Laser Diffractometry: Comparison with the Sieve-Pipette Method. Catena, 32(3-4), 193-208. https://doi.org/10.1016/S0341-8162(98)00051-4

Bienvenue, A., Jiménez-Flores, R., \& Singh, H. (2003). Rheological Properties of Concentrated Skim Milk: Importance of Soluble Minerals in the Changes in Viscosity During Storage. Journal of Dairy Science, 86(12), 3813-3821. https://doi.org/10.3168/jds.S0022-0302(03)73988-5

Bildyukevich, A. V., Plisko, T. V., Lipnizki, F., \& Pratsenko, S. A. (2020). Correlation Between Membrane Surface Properties, Polymer Nature and Fouling in Skim Milk Ultrafiltration. Colloids and Surfaces A: Physicochemical and Engineering Aspects, 605, 125387. https://doi.org/10.1016/j.colsurfa.2020.125387

Bista, A., Tobin, J. T., O’Donnell, C. P., \& O’Shea, N. (2020). Monitoring Viscosity and Total Solids Content of Milk Protein Concentrate Using an Inline Acoustic Flowmeter at Laboratory Scale. Foods, 9(9). https://doi.org/10.3390/foods9091310

Bloore, C., \& Boag, I. (1981). Some Factors Affecting the Viscosity of Concentrated Skim Milk. New Zealand Journal of Dairy Science and Technology, 16(2), 143-154.

Briuglia, M. L., Sefcik, J., \& Horst, J. H. T. (2019). Measuring Secondary Nucleation Through Single Crystal Seeding. Crystal Growth and Design, 19(1), 421429. https://doi.org/10.1021/acs.cgd.8b01515

Bronlund, J., \& Paterson, T. (2004). Moisture Sorption Isotherms for Crystalline, Amorphous and Predominantly Crystalline Lactose Powders. International Dairy Journal, 14(3), 247-254.

Bylund, G. (1995). Dairy Processing Handbook. (1st ed.). Tetra Park Processing Systems AB.

Chen, Z., Wu, T., Yang, X., Yue, F., \& Fu, F. (2020). An Exploration of the Solvent- and Acid-Catalyzed Mutarotation Mechanisms of Lactose in Aqueous Solution. New Journal of Chemistry, 44(38), 16421-16430. https://doi.org/10.1039/d0nj03660a

Cheng, D. (1987). Thixotropy. International Journal of Cosmetic Science, 9(4), 151-191.

Chernov, A. A. (1989). Formation of Crystals in Solutions. Contemporary Physics, 30(4), 251-276. 
Choscz, C., Held, C., Eder, C., Sadowski, G., \& Briesen, H. (2019). Measurement and Modeling of Lactose Solubility in Aqueous Electrolyte Solutions. Industrial and Engineering Chemistry Research, 58(45), 20797-20805. https://doi.org/10.1021/acs.iecr.9b04031

Cuartas-Uribe, B., Alcaina-Miranda, M. I., Soriano-Costa, E., Mendoza-Roca, J. A., Iborra-Clar, M. I., \& Lora García, J. (2009). A Study of the Separation of Lactose from Whey Ultrafiltration Permeate Using Nanofiltration. Desalination, 241(1-3), 244-255. https://doi.org/10.1016/j.desal.2007.11.086

Darcy, P., \& Buckton, G. (1998). Crystallization of Bulk Samples of Partially Amorphous Spray-Dried Lactose. Pharmaceutical Development and Technology, 3(4), 503-507. https://doi.org/10.3109/10837459809028632

Darmali, C., Mansouri, S., Yazdanpanah, N., \& Woo, M. W. (2019). Mechanisms and Control of Impurities in Continuous Crystallization: A Review. Industrial and Engineering Chemistry Research, 58(4), 1463-1479. https://doi.org/10.1021/acs.iecr.8b04560

Edgar, S., \& Axel, M. (1998). Milk and Dairy Product Technology (1st ed.). Routledge. https://doi.org/10.1201/9780203747162

Enayati, M., Gong, Y., Goddard, J. M., \& Abbaspourrad, A. (2018). Synthesis and Characterization of Lactose Fatty Acid Ester Biosurfactants Using Free and Immobilized Lipases in Organic Solvents. Food Chemistry, 266, 508-513. https://doi.org/10.1016/j.foodchem.2018.06.051

Fan, F., Liu, M., Shi, P., Xu, X., Lu, W., Wang, Z., \& Du, M. (2018). Protein Cross-Linking and the Maillard Reaction Decrease the Solubility of Milk Protein. Concentrates. Food Science and Nutrition, 6(5), 1196-1203. https://doi.org/10.1002/fsn3.657

Fang, Y., Selomulya, C., Ainsworth, S., Palmer, M., \& Chen, X. (2011). On Quantifying the Dissolution Behaviour of Milk Protein Concentrate. Food Hydrocolloids, 25(3), 503-510. https://doi.org/10.1016/j.foodhyd.2010.07.030

Ferrer, M. A., Hill, A. R., \& Corredig, M. (2008). Rheological Properties of Rennet Gels Containing Milk Protein Concentrates. Journal of Dairy Science, 91(3), 959-969. https://doi.org/10.3168/jds.2007-0525

Fitzpatrick, J. J., Hodnett, M., Twomey, M., Cerqueira, P. S. M., O’Flynn, J., \& Roos, Y. H. (2007). Glass Transition and the Flowability and Caking of Powders Containing Amorphous Lactose. Powder Technology, 178(2), 119128. https://doi.org/10.1016/j.powtec.2007.04.017

Fox, P. F., \& Brodkorb, A. (2008). The Casein Micelle: Historical Aspects, Current Concepts and Significance. International Dairy Journal, 18(7), 677-684.

Galenko, P. K., \& Ankudinov, V. (2019). Local Non-Equilibrium Effect on the Growth Kinetics of Crystals. Acta Materialia, 168, 203-209. https://doi.org/10.1016/j.actamat.2019.02.018

Gänzle, M. G., Haase, G., \& Jelen, P. (2008). Lactose: Crystallization, Hydrolysis and Value Added Derivatives. International Dairy Journal, 18(7), 685-694. https://doi.org/10.1016/j.idairyj.2008.03.003

Gavazzi-April, C., Benoit, S., Doyen, A., Britten, M., \& Pouliot, Y. (2018). Preparation of Milk Protein Concentrates by Ultrafiltration and Continuous Diafiltration: Effect of Process Design on Overall Efficiency. Journal of Dairy Science, 101(11), 9670-9679. https://doi.org/10.3168/jds.2018-14430

Ghadipasha, N., Romagnoli, J. A., Tronci, S., \& Baratti, R. (2018). A Model-Based Approach for Controlling Particle Size Distribution in Combined CoolingAntisolvent Crystallization Processes. Chemical Engineering Science, 190, 260-272. https://doi.org/10.1016/j.ces.2018.06.032

Goulart, D. B., \& Hartel, R. W. (2017). Lactose Crystallization in Milk Protein Concentrate and its Effects on Rheology. Journal of Food Engineering, 212, 97107. https://doi.org/10.1016/j.jfoodeng.2017.05.012

Gutiérrez-Méndez, N. (2020). Lactose. In N. Gutiérrez-Méndez (Ed.), Lactose and Lactose Derivatives. IntechOpen. https://doi.org/10.5772/intechopen.87477

Harper, W. (1992). Lactose and Lactose Derivatives. In J. Zadow (Ed.), Whey and Lactose Processing 336-346. Springer. https://doi.org/10.1007/978-94-0112894-0_9

Havea, P. (2006). Protein Interactions in Milk Protein Concentrate Powders. International Dairy Journal, 16(5), 415- 422. https://doi.org/10.1016/j.idairyj.2005.06.005

Hayashi, H., \& Kudo, N. (1989). Effect of Viscosity on Spray Drying of Milk - Reports of Research Laboratory.

Hebbink, G., \& Dickhoff, B. (2019). Application of Lactose in the Pharmaceutical Industry. In Lactose: Evolutionary Role, Health Effects, and Applications (pp. 175-229). https://doi.org/10.1016/B978-0-12-811720-0.00005-2

Herrington, B. L. (1934). Some Physico-Chemical Properties of Lactose: II. Factors Influencing the Crystalline Habit of Lactose. Journal of Dairy Science, 17(8), 533-542. https://doi.org/10.3168/jds.S0022-0302(34)93270-7

Hiemenz, P., \& Rajagopalan, R. (1997). Principles of Colloid and Surface Chemistry (3rd ed.). Taylor \& Francis Group.

Ho, Q. T., Murphy, K. M., Drapala, K. P., Fenelon, M. A., O’Mahony, J. A., Tobin, J. T., \& McCarthy, N. A. (2019). Modelling the Changes in Viscosity During Thermal Treatment of Milk Protein Concentrate Using Kinetic Data. Journal of Food Engineering, 246, 179-191.

https://doi.org/10.1016/j.jfoodeng.2018.10.026

Ho, Q. T., Murphy, K. M., Drapala, K. P., O’Callaghan, T. F., Fenelon, M. A., O’Mahony, J. A., \& McCarthy, N. A. (2018). Effect of pH and Heat Treatment on Viscosity and Heat Coagulation Properties of Milk Protein Concentrate. International Dairy Journal, 85, $219-224$. https://doi.org/10.1016/j.idairyj.2018.05.012

Holsinger, V. (1988). Lactose. In N. Wong, R. Jenness, M. Keeney, \& E. Marth (Eds.), Fundamentals of Dairy Chemistry (3rd ed., pp. 279-342). Van Nostrand Reinhold Co. 
Holsinger, V. (1997). Physical and Chemical Properties of Lactose. In Advanced Dairy Chemistry (2nd ed., pp. 1-38). Chapman \& Hall.

Huffman, L. M., \& Harper, W. J. (1999). Maximizing the Value of Milk Throug Separation Technologies. Journal of Dairy Science, 82(10), 2238-2244. https://doi.org/10.3168/jds.S0022-0302(99)75471-8

Hunziker, O. (1934). Condensed Milk And milk Powder (5th ed.).

Hunziker, O. F., \& Nissen, B. H. (1926). Lactose Solubility and Lactose Crystal Formation: I. Lactose Solubility. Journal of Dairy Science, 9(6), $517-537$.

Jawad, R., Elleman, C., Vermeer, L., Drake, A. F., Woodhead, B., Martin, G. P., \& Royall, P. G. (2012). The Measurement of the Beta/Alpha Anomer Composition within Amorphous Lactose Prepared by Spray and Freeze Drying Using a Simple 1H-NMR Method. Pharmaceutical Research, 29(2), 511 524.https://doi.org/10.1007/s11095-011-0575-6

Jenness, R., \& Holt, C. (1987). Casein and Lactose Concentrations in Milk of 31 Species are Negatively Correlated. Experientia, 43(9), 1015-1018. https://doi.org/10.1007/BF01952224

Kawashima, Y. (2019). Concept of Spherical Crystallization. In Spherical Crystallization as a New Platform for Particle Design Engineering (pp. 11-18). Springer, Singapore. https://doi.org/10.1007/978-981-13-6786-1_2

Knipschildt, M., \& Andersen, G. (1993). Drying of Milk and Milk Products. In R. Robinson (Ed.), Modern Dairy Technology (2nd ed., p. 516). Chapman \& Hall.

Le, T., Bhandari, B., \& Deeth, H. (2011). Chemical and Physical Changes in Milk Protein Concentrate (MPC80) Powder During Storage. Journal of Agricultural and Food Chemistry, 59, 5465-5473. https://doi.org/10.1021/jf2003464

Lefort, R., Caron, V., Willart, J. F., \& Descamps, M. (2006). Mutarotational Kinetics and Glass Transition of Lactose. Solid State Communications, 140(7-8), 329-334. https://doi.org/10.1016/j.ssc.2006.09.003

Levi, A., \& Kotrla, M. (1997). Theory and Simulation of Crystal Growth. Journal of Physics: Condensed Matter, 9, 299. https://doi.org/10.1088/0953$8984 / 9 / 2 / 001$

Li, B., Waldron, D., Tobin, J., Subhir, S., Kelly, A., \& McSweeney, P. (2020). Evaluation of Production of Cheddar Cheese from Micella Casein Concentrate. International Dairy Journal, 107. https://doi.org/10.1016/j.idairyj.2020.104711

Li, K., Woo, M. W., Patel, H., Metzger, L., \& Selomulya, C. (2018). Improvement of Rheological and Functional Properties of Milk Protein Concentrate by Hydrodynamic Cavitation. Journal of Food Engineering, 221, 106-113. https://doi.org/10.1016/j.jfoodeng.2017.10.005

Listiohadi, Y., Hourigan, J., Sleigh, R., \& Steele, R. (2005). Properties of Lactose and its Caking Behaviour. Australian Journal of Dairy Technology, 60(1), 33-52.

Marsh, B. (1988). Crystal Size Sistribution (CSD) in Rocks and the Kinetics and Dynamics of Crystallization. Contributions to Mineralogy and Petrology, 99, 277-291. https://doi.org/10.1007/BF00375362

Matusevich, L., \& Blinova, N. (1964). Isohydric Crystallization at Different Solution Cooling Rates. Russian Journal of Applied Chemistry.

May, A. F., Yan, J., \& McGuire, M. A. (2020). A Practical Guide for Crystal Growth of Van der Waals Layered Materials. Journal of Applied Physics, 128(5). https://doi.org/10.1063/5.0015971

McLeod, J., Paterson, A. H. J., Jones, J. R., \& Bronlund, J. E. (2011). Primary Nucleation of Alpha-Lactose Monohydrate: The Effect of Supersaturation and Temperature. International Dairy Journal, 21(7), 455-461. https://doi.org/10.1016/j.idairyj.2011.01.006

McSweeney, P., \& Fox, P., R. P. (1958). Lactose Symposium: Physical and Chemical Aspects of Lactose. Journal of Dairy Science, 41(2), 319-324.

McSweeney, P., \& Fox, P. (Eds.). (2009). Advanced Dairy Chemistry - Lactose, Water, Salts and Vitamins (3rd ed.). Springer Science+Business Media. https://doi.org/10.1007/978-0-387-84865-5

Mezger, T. (2006). The Rheology Handbook: For Users of Rotational and Oscillatory Rheometer (2nd ed.). Vincentz Network GmbH \& Co.

Mi, X., Hou, Z., Li, X., Liu, H., \& Guo, X. (2020). Synergistic Effect Between Organic Structure-Directing Agent and Crystal Seed Toward Controlled Morphology, and Bimodal Pore Structure of Aggregated Nanosized ZSM-5. Microporous and Mesoporous Materials, 302, 110255.

https://doi.org/10.1016/j.micromeso.2020.110255

Miao, S., \& Roos, Y. H. (2005). Crystallization Kinetics and X-Ray Diffraction of Crystals Formed in Amorphous Lactose, Trehalose, and Lactose/Trehalose Mixtures. Journal of Food Science, 70(5), 350-358. https://doi.org/10.1111/j.1365-2621.2005.tb09976.x

Mistry, VV. (2002). Manufacture and Application of High Milk Protein Powder. Lait, 82(4), 515-522. https://doi.org/10.1051/lait:2002028

Mistry, V. V., \& Hassan, H. N. (1991). Delactosed, High Milk Protein Powder. 1. Manufacture and Composition. Journal of Dairy Science, 74(4), $1163-1169$.

Moeck, P. (2018). Towards Generalized Noise-Level Dependent Crystallographic Symmetry Classifications of More or Less Periodic Crystal Patterns. Symmetry, 10(5). https://doi.org/10.3390/sym10050133

Morrison, F. (2001). Understanding Rheology. Oxford University Press.

Mullin, J. (2001). Crystallization (4th ed.). Butterworth Heinemann.

Myerson, A., \& Ginde, R. (2002). Crystal, Crystal Growth and Nucleation. In A. Myerson (Ed.), Handbook of Industrial Crystallization (2nd ed., pp. 33-63). 
Butterworth-Heinemann.

Nanev, C. N. (2020). Relationship Between Number and Sizes of Crystals Growing in Batch Crystallization: Nuclei Number Density, Nucleation Kinetics and Crystal Polydispersity. Journal of Crystal Growth, 546(June), 125786. https://doi.org/10.1016/j.jcrysgro.2020.125786

Nickerson, T. A. (1954). Lactose Crystallization in Ice Cream. I. Control of Crystal Size by Seeding. Journal of Dairy Science, 37(9), $1099-1105$. https://doi.org/10.3168/jds.S0022-0302(54)91373-9

Nickerson, T. A. (1962). Lactose Crystallization in Ice Cream. IV. Factors Responsible for Reduced Incidence of Sandiness. Journal of Dairy Science, 45(3), 354-359. https://doi.org/10.3168/jds.S0022-0302(62)89398-9

Nickerson, T. A. (1979). Lactose Chemistry. Journal of Agricultural and Food Chemistry, 27(4), 672-677.

Nikitina, E., Ahmad Riyanto, R., Vafina, A., Yurtaeva, T., \& Tsyganov, Galina Ezhkova, M. (2019). Effect of Fermented Modified Potato Starches to Low-Fat Yogurt. Journal of Food and Nutrition Research, 7(7), 549-553. https://doi.org/10.12691/jfnr-7-7-10

O’Donoghue, L. T., Haque, M. K., Kennedy, D., Laffir, F. R., Hogan, S. A., O’Mahony, J. A., \& Murphy, E. G. (2019). Influence of Particle Size on the Physicochemical Properties and Stickiness of Dairy Powders. International Dairy Journal, 98, 54-63. https://doi.org/10.1016/j.idairyj.2019.07.002

Olson, I. A., Shtukenberg, A. G., Kahr, B., \& Ward, M. D. (2018). Dislocations in Molecular Crystals. Reports on Progress in Physics, 81(9). https://doi.org/10.1088/1361-6633/aac303

O’Sullivan, J. J., Norwood, E. A., O’Mahony, J. A., \& Kelly, A. L. (2019). Atomisation Technologies Used in Spray Drying in the Dairy Industry: A Review. Journal of Food Engineering, 243, 57-69. https://doi.org/10.1016/j.jfoodeng.2018.08.027

Özkan, N., Walisinghe, N., \& Chen, X. D. (2002). Characterization of Stickiness and Cake Formation in Whole and Skim Milk Powders. Journal of Food Engineering, 55(4), 293-303. https://doi.org/10.1016/S0260-8774(02)00104-8

Pandalaneni, K., \& Amamcharla, J. K. (2018). Evaluating the Crystallization of Lactose at Different Cooling Rates From Milk and Whey Permeates in Terms of Crystal Yield and Purity. Journal of Dairy Science, 101(10), 8805-8821. https://doi.org/10.3168/jds.2018-14846

Pangborn, R., \& Gee, S. (1961). Relative Sweetness of Alpha and Beta Forms of Selected Sugars. Nature, 191, 810-811. https://doi.org/10.1038/191810a0

Pangborn, R. (1963). Relative Taste Intensities of Selected Sugars and Organic Acids. Journal of Food Science, 28, $726-733$.

Patel, K. N., \& Nickerson, T. A. (1970). Influence of Sucrose on the Mutarotation Velocity of Lactose. Journal of Dairy Science, 53(12), 1654-1658. https://doi.org/10.3168/jds.S0022-0302(70)86458-X

Peleg, M. (2018). Temperature-Viscosity Models Reassessed. Critical Reviews in Food Science and Nutrition, 58(15), 2663-2672. https://doi.org/10.1080/10408398.2017.1325836

Rehman, S. U., Farkye, N. Y., Considine, T., Schaffner, A., \& Drake, M. A. (2003). Effects of Standardization of Whole Milk with Dry Milk Protein Concentrate on the Yield and Ripening of Reduced Fat Cheddar Cheese. Journal of Dairy Science, 86(5), 1608-1615.

Rodier, L. C., \& Hartel, R. W. (2021). Characterizing Maillard Reaction Kinetics and Rheological Changes in White Chocolate over Extended Heating. Journal of Food Science, 86(6), 2553-2568. https://doi.org/10.1111/17503841.15772

Roos, Y. (2002). Importance of Glass Transition and Water Activity to Spray Drying and Stability of Dairy Powders. Lait, 82, $475-484$.

Saxena, J., Adhikari, B., Brkljaca, R., Huppertz, T., Zisu, B., \& Chandrapala, J. (2021). Influence of Lactose Pre-Crystallization on the Storage Stability of Infant Formula Powder Containing Lactose and Maltodextrin. Food Hydrocolloids, 111, 106385. https://doi.org/10.1016/j.foodhyd.2020.106385

Schuck, P., Mejean, S., Dolivet, A., Beaucher, E., \& Famelart, M. (2005). Pump Amperage: A New Method for Monitoring Viscosity of Dairy Concentrates Before Spray Drying. Lait, 85, 361-367. https://doi.org/10.1051/lait:2005014

Shah, B., McCabe, W., \& Rousseau, R. (1973). Polyethlene Versus Stainless Steel Impellers for Crystallization Processes. American Institute of Chemical Engineers Journal, 19, 194.

Sherbon, J. (1988). Physical Properties of Milk. In N. Wong, R. Jenness, M. Keeney, \& E. Marth (Eds.), Fundamentals of Dairy Chemistry (3rd ed., pp. 409460). Van Nostrand Reinhold.

Shi, Y., Hartel, R. W., \& Liang, B. (1989). Formation and Growth Phenomena of Lactose Nuclei under Contact Nucleation Conditions. Journal of Dairy Science, 72(11), 2906-2915. https://doi.org/10.3168/jds.S0022-0302(89)79441-8

Shi, Y., Liang, B., \& Hartel, R. (2006). Crystal Refining Technologies by Controlled Crystallization (Patent No. US20060128953A1). https://patents.google.com/patent/US20060128953A1/en

Sienkiewicz, T., \& Riedel, C. (1990). Whey and Whey Utilization (2nd ed.). Verlag Th Mann GmbH.

Sikand, V., Tong, P. S., Roy, S., Rodriguez-Saona, L. E., \& Murray, B. A. (2011). Solubility of Commercial Milk Protein Concentrates and Milk Protein Isolates. Journal of Dairy Science, 94(12), 6194-6202. https://doi.org/10.3168/jds.2011-4477

Smart, J., Haylock, S., \& Gordon, M. (1991). Lactose - An Underutilized Food Ingredient. Food Australia, 43(9), 386-388.

Smith, K., Mittal, G., \& Griffiths, M. (2006). Pasteurization of Milk Using Pulsed Electrical Field and Antimicrobials. Journal of Food Science, 67(6), 23042308. https://doi.org/10.1111/j.1365-2621.2002.tb09545.x 
Smithers, G., \& Augustin, M. (2013). Advances In Dairy Ingredients (1st ed.). Wiley-Blackwell. https://doi.org/10.1002/9781118448205

Snoeren, T., Damman, A., \& Klok, H. (1982). The Viscosity of Skim Milk Concentrates. Netherlands Milk and Dairy Journal, 36, 305-316.

Taibi, H., \& Messelmi, F. (2018). Effect of Yield Stress on the Behavior of Rigid Zones During the Laminar Flow of Herschel-Bulkley Fluid. Alexandria Engineering Journal, 57(2), 1109-1115. https://doi.org/10.1016/j.aej.2017.01.001

Tan, R. (2009). Manufacture of Sweetened Condensed Milk and the Significance of Lactose Therein. In Advanced Dairy Chemistry - Lactose, Water, Salts and Minor Constituents (3rd ed., pp. 36-57). Springer.

Teixeira, G., Malagoni, R., Gonçalves, R., \& Finzer, J. (2020). Study of Lactose Crystallization in a Vibrated Bed with High Seeding through a Central Composite Design. Research, Society and Development, 9(8). https://doi.org/10.33448/rsd-v9i8.5734

Toledo, R. (1991). Fundamentals of Food Process Engineering (3rd ed.). Springer US.

Troy, H., \& Sharp, P. (1930). Alpha and Beta Lactose in Some Milk Products. Journal of Dairy Science, 13, 140-157

Urashima, T., Katayama, T., Sakanaka, M., Fukuda, K., \& Messer, M. (2021). Evolution of Milk Oligosaccharides: Origin and Selectivity of the Ratio of Milk Oligosaccharides to Lactose Among Mammals. Biochimica et Biophysica Acta (BBA)-General Subjects, 1866(1). https://doi.org/10.1016/j.bbagen.2021.130012

Van Kreveld, A. (1969). Growth Rates of Lactose Crystals in Solutions of Stable Anhydrous Alpha-Lactose. Netherlands Milk and Dairy Journal, $23,258-275$.

Van Kreveld, A., \& Michaels, A. S. (1965). Measurement of Crystal Growth of Alpha-Lactose. Journal of Dairy Science, 48, $259-265$.

Walstra, P., Geurts, T., Noomen, A., Jellema, A., \& Boekel, M. (1999). Dairy Technology - Principles of Milk Properties and Processes (1st ed.). Marcel Dekker, Inc. https://doi.org/10.1201/9780824746414

Walstra, P., Geurts, T., Noomen, A., Jellema, A., \& Boekel, M. (2001). Ciência de la Leche y Tecnología de los Produtos Lácteos. Acribia.

Wong, S. Y., Bund, R. K., Connelly, R. K., \& Hartel, R. W. (2011). Determination of the Dynamic Metastable Limit for Alpha-Lactose Monohydrate Crystallization. International Dairy Journal, 21(11), 839-847. https://doi.org/10.1016/j.idairyj.2011.05.003

Xiang, J., Liu, F., Wang, B., Chen, L., Liu, W., \& Tan, S. (2021). A Literature Review on Maillard Reaction Based on Milk Products : Advantages, Disadvantages, and Avoidance Strategies. MDPI Foods, 10. https://doi.org/10.3390/foods10091998

Xu, S., Wang, Y., Hou, Z., \& Chuai, X. (2020). Overview of Secondary Nucleation: From Fundamentals to Application. Industrial and Engineering Chemistry Research, 59(41), 18335-18356. https://doi.org/10.1021/acs.iecr.0c03304

Zhang, F., Mohammadi, E., Luo, X., Strzalka, J., Mei, J., \& Diao, Y. (2018). Critical Role of Surface Energy in Guiding Crystallization of Solution-Coated Conjugated Polymer Thin Films. Langmuir, 34(3), 1109-1122. https://doi.org/10.1021/acs.langmuir.7b02807

Zhang, J., Liu, D., Liu, Y., Yu, Y., Hemar, Y., Regenstein, J., \& Zhou, P. (2020). Effects of Particle Size and Aging of Milk Protein Concentrate on the Biophysical Properties of an Intermediate-Moisture Model Food System. Food Bioscience, 37. https://doi.org/10.1016/j.fbio.2020.100698

Zhang, Y., Munir, M. T., Udugama, I., Yu, W., \& Young, B. R. (2018). Modelling of a Milk Powder Falling Film Evaporator for Predicting Process Trends and Comparison of Energy Consumption. Journal of Food Engineering, 225, 26-33. https://doi.org/10.1016/j.jfoodeng.2018.01.016 